\title{
Notas Críticas do Direito Processual ao Artigo 23 da Lei Complementar no 64, de 1990
}

\author{
Critical Notes of the Procedural Law to Article 23 of Complementary \\ Law n 64, of 1990
}

Rodolfo Viana Pereira

Lucas Tavares Mourão

Resumo: No trabalho que se desenvolve é feito um levantamento de como o Novo Código de Processo Civil trabalha a garantia do contraditório substancial na instrução processual, e como fica o papel do juiz na condução dos trabalhos ao primar pela isonomia das partes, pela manifestação perante todos os fatos apresentados e pela fundamentação de suas decisões. Contrapõe-se a essa sistemática a interpretação que é conferida ao art. 23, da Lei das Inelegibilidades, o qual permite que sejam proferidas decisões a partir da livre apreciação de fatos notórios, indícios e presunções trazidos de ofício pelo magistrado, sem que proporcione a manifestação das partes sobre eles. Ao final é mostrado que, embora alguns doutrinadores e o Supremo Tribunal Federal entendam não haver irregularidade no texto do artigo, seu conflito com o sistema processual e o Novo CPC é flagrante, sendo necessário ao aplicador do direito recorrer às técnicas de resolução de incompatibilidade de normas para aplicar as diretivas do código processual, seja supletiva ou subsidiariamente ao processo eleitoral, a depender de sua leitura sobre o conflito entre as normas.

Palavras-chave: Contraditório substancial. Novo CPC. Lei das Inelegibilidades. Conflito de normas.
Abstract: In the work that takes place, a data entry is made of how the New Code of Civil Procedure works to guarantee the substantial contradiction in the procedural instruction and how the role of the judge in the conduct of the work is prevail by the isonomy of the parties, by the manifestation before all the facts presented and the reasons for its decisions. This system is opposed to the interpretation given to art. 23 of the Law on Ineligibilities, which allows judgments to be made based on the free appreciation of notorious facts, indications and presumptions brought "of office" by the magistrate, without giving the manifestation of the parties on them. In the end, it is shown that, although some writers and the Federal Supreme Court understand that there is no irregularity in the text of the article, its conflict with the procedural system and the New CPC is flagrant, requiring the applicator of the law the right to recall to the techniques of resolution of incompatibility of rules to apply the directives of the procedural code, be it supplementary or subsidiary to the electoral process, depending on its reading on the conflict between the norms.

Keywords: Substantial contradiction. New CPC. Law of Ineligibilities. Conflict of norms.

Artigo recebido em 29 ago. 2017 e aprovado em 22 set. 2017. 


\section{Introdução}

O estudo da legislação e da jurisprudência eleitorais mostra uma tendência crescente na busca pela moralidade pública em detrimento das garantias fundamentais. Instrumentos como a Lei das Inelegibilidades (Lei Complementar n⿳o 64/1990), a Lei da Ficha Limpa (Lei Complementar no 135/2010), bem como as diversas reformas e resoluções do Tribunal Superior Eleitoral cerceando a liberdade de propaganda, mostram como o exercício do sufrágio passivo tem sido mitigado por ser visto como um perigo em potencial à sociedade. Soma-se a isso a postura de guardião moral adotada pelos juízes e tribunais eleitorais, decidindo in dubio pro societate em decisões reiteradamente criticadas pela doutrina.

Em sentido diametralmente oposto, evolui a teoria do processo. Com a entrada em vigor do Novo Código de Processo Civil deu-se ênfase ao contraditório substancial, exaltando o papel do magistrado na condução do processo. O novo instrumento aprovado busca garantir uma construção dialética da verdade, na qual as partes litigantes têm assegurada a paridade de armas em todas as fases, devendo ser-lhes oportunizado o direito de manifestação frente a qualquer fato e prova apresentados, mesmo que de ofício pelo juiz. Ao mesmo tempo em que o Novo CPC aumenta o dever do julgador em fundamentar suas decisões e prezar pela isonomia entre as partes, retira dele a carga subjetivista do livre convencimento, vinculando-o mais à verdade construída por meio do contraditório.

A ampla divergência entre os dois ramos do Direito gera atrito quando postos de frente. Sabe-se que o Código de Processo Civil se aplica supletiva e subsidiariamente ao processo eleitoral (art. 15). Mas, sendo assim, qual ideologia deveria prevalecer na condução de processo eleitoral, por exemplo, de uma Ação de Investigação Judicial Eleitoral? As garantias do Direito Processual ou a busca pela moralidade que vem pautando a atuação do Direito Eleitoral?

Este trabalho se propõe a investigar esse embate, especificamente no tocante ao art. 23, da LC no 64/90. Para tanto, buscou-se, com base em literatura especializada, levantar críticas de como as garantias processuais são interpretadas pelos ramos em questão e, ao fim, endossar as propostas de uma solução para o conflito normativo verificado. 


\section{O Novo CPC e o Reforço do Contraditório Substancial pela Atuação do Magistrado}

A Lei n⿳⺈ 13.105/2015, que instituiu o novo Código de Processo Civil, trouxe alterações significativas em diversos aspectos do rito processual no Direito brasileiro. Uma das principais perspectivas com o novo codex é a ampliação da garantia às partes de maior isonomia durante a instrução processual de uma lide. Para tanto, reforça-se a postura do magistrado que conduz o processo como partícipe atuante na relação processual, distanciando-se cada vez mais da acepção de mero espectador distante que se incumbia apenas de receber os fatos e dizer o direito, conforme o brocardo dami factum dabo tibi jus.

Em verdade, o crescimento da participação do juiz é um fenômeno que se pode perceber já há algum tempo, como se denota das lições que Cintra, Grinover e Dinamarco (2014) tecem sobre a interpretação evolutiva do princípio dispositivo. Explicam os autores que a origem do referido princípio remonta a um sentido liberal de que o juiz imparcial e não inquisitivo dependeria exclusivamente da manifestação das partes quanto às provas e alegações para a instrução do processo. No entanto, com o crescimento da acepção publicista do processo, o magistrado passou a assumir postura mais ativa para determinar provas e conhecer determinadas matérias ex officio.

Essa evolução levou Theodoro Jr. (2011), ainda sob a égide do antigo CPC, a alegar que as legislações processuais são hoje mistas, misturando preceitos inquisitivos e dispositivos, mas com a observação de que embora o juiz possa ordenar a produção de provas não requeridas pelas partes, não pode se tornar um investigador ou inquisidor.

Ainda no Código de 1973, outro reforço ao alcance de atuação do magistrado foi a positivação da apreciação das provas sem que elas fossem tarifadas, quer dizer, sem que tivessem peso legal. Falava-se do livre convencimento, previsto no então art. 131 com a seguinte redação: “O juiz apreciará livremente a prova, atendendo aos fatos e circunstâncias constantes dos autos, ainda que não alegados pelas partes; mas deverá indicar, na sentença, os motivos que lhe formaram o convencimento".

Cintra e outros (2014) explicam tratar-se do princípio da persuasão racional do juiz, situado entre o sistema de prova legal e o do julgamento 
secundum conscientiam ${ }^{1}$. Alertam os referidos doutrinadores, contudo, que o juiz ainda devia se pautar pela máxima quod non est in actis non est in mundo, devendo decidir com base nos elementos constantes no processo, mas avaliando-os segundo critérios críticos e racionais.

Com a advinda do Novo CPC, ao juiz foi conferida maior participação na instrução processual, para a garantia da paridade de armas entre as partes e a realização efetiva do princípio contraditório. Fala-se, agora, em contraditório substancial, o qual encontra seu fundamento, destacadamente, nos artigos 7², 9ํㅜ e 10 do código:

Art. 7 ํ É assegurado às partes paridade de tratamento em relação ao exercício de direitos e faculdades processuais, aos meios de defesa, aos ônus, aos deveres e à aplicação de sanções processuais, competindo ao juiz zelar pelo efetivo contraditório.

Art. 9ํNão se proferirá decisão contra uma das partes sem que ela seja previamente ouvida.

Art. 10. O juiz não pode decidir, em grau algum de jurisdição, com base em fundamento a respeito do qual não se tenha dado às partes oportunidade de se manifestar, ainda que se trate de matéria sobre a qual deva decidir de ofício.

Restou superada a ideia meramente formal do princípio contraditório, tida de forma simplificada como aquela garantia de que às partes seriam dadas as mesmas oportunidades de manifestação. A análise substancial do princípio eleva o contraditório para além da bilateralidade das partes isoladamente consideradas, instaurando um diálogo entre elas e o magistrado, de forma a garantir uma atividade dialética, dinâmica e efetiva entre os atores envolvidos, na esteira do que leciona Theodoro Jr. (2015) ao se debruçar sobre o novo instituto.

Em material específico sobre o tema, Silva e Roberto (2014, p. 180) ensinam que o contraditório substancial se diferencia por ser efetivado "para além da argumentação ou dos poderes e faculdades retóricas das partes", deixando no passado a liberdade arbitrária de quando as partes eram largadas à sua própria competência. Consoante asseveram os autores, é de-

\footnotetext{
${ }^{1} \mathrm{Na}$ dicção dos autores, o sistema de prova legal ou tarifada "significa atribuir aos elementos probatórios valor inalterável e prefixado, que o juiz aplica mecanicamente”, enquanto no julgamento secundum conscientiam "o juiz pode decidir com base na prova dos autos mas também sem provas e até mesmo contra as provas".
}

Resenha Eleitoral (Florianópolis), v. 21, n. 1, p. 119-142, nov. 2017 
ver do juiz velar pela efetivação do contraditório, conferindo tratamento paritário às partes, mas sem interferir com seu poder na busca de uma dita verdade real (SILVA; ROBERTO, 2014).

Pode-se dizer, em linhas gerais, que a intenção do Novo CPC com o reforço do contraditório substancial é exaltar o papel do juiz não apenas como um árbitro frio e distante, mas como partícipe ativo no processo, e mediador próximo às partes na busca de uma solução do litígio. $\mathrm{O}$ faz ao garantir que todos os interessados tenham as mesmas condições de influenciar no convencimento do julgador ao final, e ao proporcionar a manifestação das partes diante de toda questão suscitada e que possa influenciar no resultado ao fim. Deve, contudo, ficar atento ao dever constitucional de fundamentação de todas as decisões, respeitando os elementos amplamente discutidos nos autos, não investindo em uma busca heroica e isolada pela verdade real.

O dever de fundamentação sobressai na construção do contraditório substancial justamente por ser a garantia de que a decisão final será construída em vista dos elementos apresentados e debatidos ao longo do processo.

Para Taruffo (2016) a fundamentação teria duas funções nítidas, uma endoprocessual e outra extraprocessual. A primeira consistiria em possibilitar às partes analisar a racionalidade da decisão, dirigindo a atividade recursal, ao passo que a última seria a possibilidade de a sociedade acompanhar o exercício do poder jurisdicional e a observância do devido processo legal, como manifestação do caráter publicista da decisão judicial.

Ramina de Lucca (2015, p. 125) esboça ainda uma terceira função, a de legitimação do poder jurisdicional, argumentando que "a atividade jurisdicional extrai a sua legitimidade de seu exercício procedimentalizado, da participação efetiva das partes no processo, e da juridicidade e racionalidade das decisões ao final proferidas”.

A função endoprocessual de Taruffo (2016) corresponde ao pensamento tradicional apontado por Cintra e outros (2014) de que a fundamentação servia apenas para possibilitar às partes a impugnação para efeito de reforma. Por outro lado, as motivações encontrariam sua função política na publicidade, com o fito de aferir a imparcialidade do juiz e a legalidade e justiça das decisões, o que corresponde à função extraprocessual de Taruffo (2016) em conjunto com a terceira via de Ramina de Lucca (2015). 
Em vista do advento do Novo CPC, e da primazia dada ao dever de fundamentação e sua relação com o contraditório substancial, mostra-se pertinente a diferenciação que Andrade Neto (2016) faz das teses sobre as funções da fundamentação. $\mathrm{O}$ autor as divide criticamente em teses fracas e teses fortes, para então sustentar o que defende ser o real propósito da fundamentação, considerando (2016, p. 365):

O primeiro, que aqui se denomina grupo das teses fracas, reúne autores que atribuem à fundamentação uma função basicamente instrumental, ou seja, consideram-na um meio para atingir determinados fins normativamente previstos e/ou desejáveis.

$[\ldots]$

O segundo grupo, das teses fortes, reúne autores que atribuem à fundamentação uma função normativa própria. Dela dependeriam a validade da decisão particularmente considerada e, de modo mais abrangente, a legitimidade do próprio poder jurisdicional.

Como preconiza Andrade Neto (apud TAVARES; AGRA, 2016, p. 366), "O dever de fundamentação tem valor jurídico próprio, para além de qualquer papel instrumental que possa vir a desempenhar no ordenamento jurídico". De outra forma não haveria de ser, principalmente estando o ordenamento jurídico sob a égide de uma normativa processual que prima pelo contraditório substancial.

Assim, mais que nunca, a fundamentação deve ser abraçada como elemento de legitimidade do ato judicial ou, nas palavras de Gonçalves (2014), requisito de regularidade que, se não observado, torna o ato passível de nulidade nos ditames do art. 93, IX, da Constituição da República.

A partir do momento em que à fundamentação é dada a devida relevância de elemento de validade da decisão judicial, não há mais como se falar em "livre convencimento" no código processual. Salgado, Valiati e Bernadelli (apud TAVARES; AGRA, 2016, p. 350) lembram que a ideia original do livre convencimento (a desvinculação da apreciação probatória pelo sistema tarifado) foi deturpada ao longo dos quarenta anos de vigência do antigo CPC, passando a ser utilizada como aval à postura ativista dos magistrados, muitas vezes elencando fatos e determinando a produção de provas ex officio, sem a devida manifestação das partes e adotando fundamentação viciada que abarcava apenas as ideias com as quais coadunavam. 
Os julgadores se viam "livres" para fundamentar e instruir como bem preferiam, segundo suas consciências, como o voto do Min. Humberto Gomes de Barros escancarou, no AgRg em EREsp nº 319.997, e que posteriormente foi alvo das críticas de Lênio Luiz Streck (apud MACHADO, 2011). Do voto mencionado extrai-se a polêmica passagem (STJ, 2003):

Não me importa o que pensam os doutrinadores. Enquanto for Ministro do Superior Tribunal de Justiça, assumo a autoridade da minha jurisdição. O pensamento daqueles que não são Ministros deste Tribunal importa como orientação. A eles, porém, não me submeto. Interessa conhecer a doutrina de Barbosa Moreira ou Athos Carneiro. Decido, porém, conforme minha consciência. Precisamos estabelecer nossa autonomia intelectual, para que este Tribunal seja respeitado. É preciso consolidar o entendimento de que os Srs. Ministros Francisco Peçanha Martins e Humberto Gomes de Barros decidem assim, porque pensam assim. E o STJ decide assim, porque a maioria de seus integrantes pensa como esses Ministros. Esse é o pensamento do Superior Tribunal de Justiça, e a doutrina que se amolde a ele. É fundamental expressarmos o que somos. Ninguém nos dá lições. Não somos aprendizes de ninguém. Quando viemos para este Tribunal, corajosamente assumimos a declaração de que temos notável saber jurídico - uma imposição da Constituição Federal. Pode não ser verdade. Em relação a mim, certamente, não é, mas, para efeitos constitucionais, minha investidura obriga-me a pensar que assim seja.

Ironia considerar que, embora o voto exarado fizesse menção a Barbosa Moreira, fato é que o doutrinador mencionado lecionava em sentido diametralmente oposto, na defesa de que quanto maior o grau de discricionariedade em uma dada questão, mais forte é a exigência de fundamentação (MOREIRA, 1978). A consciência, portanto, jamais deveria ser o fundamento cabal para uma decisão jurídica. Para evitar que essa ideia apresentada há quarenta anos acabasse se perdendo efetivamente, o Novo CPC buscou trazer uma resposta ao desvirtuamento do livre convencimento, garantindo o respeito ao dever de fundamentação das decisões a partir das provas apresentadas por e para todas as partes.

Com o novel art. 371 ficou excluída qualquer expressão similar ao "livre convencimento" da tarefa de apreciação probatória ${ }^{2}$. No mesmo

\footnotetext{
${ }^{2}$ Art. 371. O juiz apreciará a prova constante dos autos, independentemente do sujeito que a tiver promovido, e indicará na decisão as razões da formação de seu convencimento.
} 
sentido, o art. 489 trouxe como elemento essencial da sentença a fundamentação, elencando no seu parágrafo primeiro as situações nas quais a decisão não pode ser considerada como fundamentada ${ }^{3}$. Nada mais correto, vez que a fundamentação, elemento essencial da decisão, é indispensável à garantia do contraditório efetivo e, como já dizia Theodoro Jr. (2011), o juiz também se submete ao contraditório, devendo observá-lo mesmo quando da deliberação de matérias apreciáveis de ofício, a respeito das quais cabe tecer algumas considerações.

Com a superação da acepção liberal do princípio dispositivo e o aumento da participação do magistrado na produção das provas necessárias à solução da lide, passou-se a admitir que o juiz conhecesse determinadas matérias de ofício. Atenta-se que, mesmo sob o regime processual passado, ao juiz era vedado levar em consideração fatos apreciados de ofício, não alegados pelas partes, sem que ambos os lados tivessem a oportunidade de se manifestarem a respeito (DIDIER JR., 2011).

\footnotetext{
${ }^{3}$ Art. 489. São elementos essenciais da sentença:
}

I - o relatório, que conterá os nomes das partes, a identificação do caso, com a suma do pedido e da contestação, e o registro das principais ocorrências havidas no andamento do processo;

II - os fundamentos, em que o juiz analisará as questões de fato e de direito;

III - o dispositivo, em que o juiz resolverá as questões principais que as partes lhe submeterem.

\1º Não se considera fundamentada qualquer decisão judicial, seja ela interlocutória, sentença ou acórdão, que:

I - se limitar à indicação, à reprodução ou à paráfrase de ato normativo, sem explicar sua relação com a causa ou a questão decidida;

II - empregar conceitos jurídicos indeterminados, sem explicar o motivo concreto de sua incidência no caso;

III - invocar motivos que se prestariam a justificar qualquer outra decisão;

IV - não enfrentar todos os argumentos deduzidos no processo capazes de, em tese, infirmar a conclusão adotada pelo julgador;

$\mathrm{V}$ - se limitar a invocar precedente ou enunciado de súmula, sem identificar seus fundamentos determinantes nem demonstrar que o caso sob julgamento se ajusta àqueles fundamentos;

VI - deixar de seguir enunciado de súmula, jurisprudência ou precedente invocado pela parte, sem demonstrar a existência de distinção no caso em julgamento ou a superação do entendimento. 
No novo sistema processual o art. 493 reforça esse entendimento, enfatizando em seu parágrafo único ${ }^{4}$ que a apreciação de qualquer fato novo, mesmo que constatado ex officio, deve ser precedida de manifestação das partes a respeito, ou, então, o magistrado não terá cumprido seu papel na garantia do contraditório efetivo.

Theodoro Jr. (2015) alerta que, não havendo a submissão da matéria apreciada de ofício às partes para que se manifestem, o juiz não poderá usá-la como fundamento da decisão ${ }^{5}$; e, como apontado, sem a devida fundamentação não há validade do ato judicial. Cunha (2013) vai além e defende que mesmo a questão submetida a julgamento por presunção simples do juiz deve ser submetida ao contraditório, sob pena de deslegitimar e invalidar o ato.

A importância que essa leitura do contraditório dá à submissão de qualquer matéria à manifestação das partes encontra sua razão de ser no princípio da não surpresa, o qual, como o próprio nome indica, pressupõe que as decisões judiciais não podem surpreender as partes com elementos desconhecidos por elas e frustrar suas legítimas expectativas (CUNHA, 2013). É a forma que o Novo CPC apresenta, como pontuam Ferreira e Mezzaroba (apud TAVARES; AGRA, 2016), de garantir estabilidade e previsibilidade para as partes no processo.

Em suma, leitura que se pode fazer do reforço que o Novo Código de Processo Civil dá ao contraditório substancial é que o instituto busca garantir que as partes de um processo tenham maior paridade de armas na formação do convencimento do juiz. Para tanto, o magistrado assume o dever de garantir que ambos os lados tenham as mesmas oportunidades de se manifestarem acerca de todos os fatos trazidos ao processo, e que possam influenciar na convicção do julgador.

O contraditório substancial também exalta o dever constitucional de fundamentação, tida como elemento de validade do ato judicial, substituindo a ideia deturpada que se criou do "livre convencimento" pelo dever de apreciação dos pontos norteadores da decisão. Esse novo olhar sobre

\footnotetext{
${ }^{4}$ Art. 493. Se, depois da propositura da ação, algum fato constitutivo, modificativo ou extintivo do direito influir no julgamento do mérito, caberá ao juiz tomá-lo em consideração, de ofício ou a requerimento da parte, no momento de proferir a decisão.

Parágrafo único. Se constatar de ofício o fato novo, o juiz ouvirá as partes sobre ele antes de decidir.

${ }^{5}$ Com as exceções do art. 9o, parágrafo único. 
o princípio contraditório visa evitar a surpresa das partes e garantir a estabilidade de uma sentença que respeite o que foi disponibilizado e discutido igualitariamente nos autos.

\section{Incompatibilidade do Art. 23 da LC no 64/90 com o Novo CPC}

Em 1990 foi promulgada a Lei Complementar no 64, trazendo os casos de inelegibilidade para candidatos a cargos eletivos e o rito para sua investigação. Apesar das alterações pelas quais o referido instrumento passou ao longo dos anos, o legislador teve por bem manter o art. 23, cuja redação suscita profundos debates desde sua entrada em vigor. Estabelece o dispositivo que:

Art. 23. O Tribunal formará sua convicção pela livre apreciação dos fatos públicos e notórios, dos indícios e presunções e prova produzida, atentando para circunstâncias ou fatos, ainda que não indicados ou alegados pelas partes, mas que preservem o interesse público de lisura eleitoral.

Percebe-se que o artigo suscitado acompanha a redação trazida pelo CPC/73 no tocante à liberdade de apreciação dos fatos. Essa ideia, como mencionado no tópico anterior, foi deturpada ao longo do tempo, servindo de guarida a decisões sem fundamentação adequada por parte dos juízes. No cenário eleitoral, arrisca-se dizer, a prática é ainda mais recorrente, como critica Salgado e outros (apud TAVARES; AGRA, 2016, p. 340), ao pontuar que o art. 23 serve para "justificar a não apreciação de todas as alegações das partes na decisão e, ainda, afastar o resultado das urnas pelo conjunto da obra”. Permite-se, como dito pelos autores, que as decisões se fundamentem no conhecimento pessoal do juiz, sem que a questão seja levada aos autos para a manifestação das partes.

Tomando por base a sistemática do Novo CPC ao abandonar o livre convencimento, seu embate com o artigo aqui discutido fica evidente já na literalidade da norma.

O problema continua em duas frentes: a possibilidade conferida ao magistrado de fundamentar sua decisão em fatos notórios, indícios e presunções; e a apreciação de fatos que não tenham necessariamente sido submetidos à manifestação das partes. Denota-se daí que a legislação eleito- 
ral permite a cassação do mandato e a imposição de pena de inelegibilidade, mesmo sem respeito ao contraditório substancial. Tudo isso em prol de um chamado "interesse público de lisura eleitoral".

A permissão de fundamentar uma decisão essencialmente em fatos notórios, em indícios e presunções esbarra em graves problemas processuais, a começar pelo subjetivismo de suas definições, ao que Streck (2014) ironiza, questionando se haveria um "notoriômetro", um "indiciômetro" e um "presunçômetro" para medi-los.

Marinoni, Arendhart e Mitidiero (2015) ensinam que fato notório não depende de prova, devendo ser aceito nessa qualidade. Caso haja discussão sobre a notoriedade de um fato, ele deixa de sê-lo, e sua existência se torna tema probatório, como lecionam Wambier, Didier Jr., Talamini e Dantas (2015).

Fica, portanto, a questão: como poderia um juiz ou tribunal eleitoral decidir uma questão com base em fatos notórios sem submetê-los às partes conflitantes para que possam questionar a real notoriedade? A presunção de notoriedade sem possibilitar às partes que se manifestem sobre o fato lhes tolhe o direito de participação no processo, e o de influenciar na convicção final do magistrado, sendo uma clara violação do princípio contraditório.

Tampouco se pode creditar uma decisão que encontre suas bases em indícios e presunções. Embora o indício seja um meio de prova, a presunção não preenche o papel nem de meio, nem de fonte de prova, existindo apenas no pensamento do juiz, como mera atividade subjetiva (DIDIER JR. et al, 2015). Nos dizeres de Theodoro Jr. (2015), as presunções são mais raciocínio que meio de prova. O grande problema, como dito por Streck (2014), é que quanto mais se dedica à subjetividade, maior o grau de insegurança e injustiças, sendo que em uma verdadeira democracia as decisões não deveriam ser produto meramente de impressões e opiniões pessoais do julgador.

Apesar das críticas dirigidas à presunção como elemento de convicção, Theodoro Jr. (2015) lembra que o Novo CPC admite a presunção de veracidade de fatos, desde que os referidos fatos não cheguem a ser objeto de prova. $\mathrm{O}$ autor reforça que, antes de acolher qualquer presunção, "a lei sempre oferece à parte oportunidade de alegar e provar a efetiva veracidade dos fatos relevantes à acolhida da ação ou da defesa" (THEDORO JR. 
2015, p. 107). E continua, alertando que apenas na efetiva falta de provas é que se legitima o julgamento por presunções, respeitando a regra de o convencimento se assentar nos fatos comprovados nos autos, como garantia do contraditório.

Visto que a doutrina processual condena a fundamentação das sentenças com base nos fatos notórios, nos indícios e nas presunções, não há como encontrar legitimidade na permissão que o art. 23 confere aos juízes eleitorais para decidirem com base nesses quesitos. Streck (2014) já levantou oportunamente: se o voto é manifestação sagrada do eleitor, sua anulação não deveria exigir provas robustas? Percebe-se que há claro conflito entre a intenção do legislador nos dois ritos processuais, o qual se projeta para a prática judicial nas diversas esferas.

Em razão dos evidentes absurdos que o art. 23 traz na construção do processo, foi apresentada a Ação Direta de Inconstitucionalidade $\mathrm{n}^{\circ}$ 1.082, em 1994, pelo Partido Socialista Brasileiro, na qual se alegou, em especial, o risco gerado à segurança jurídica, à ampla defesa e ao contraditório ${ }^{6}$. No julgamento de mérito, ocorrido vinte anos mais tarde, o voto do relator pela improcedência da ADI foi acompanhado por unanimidade, seguindo a decisão da liminar proferida anteriormente pelo Min. Néri da Silveira, ao se pautar pelo livre convencimento do art. 131, do CPC/73, que respaldava o conhecimento de matérias de ofício pelo juiz. Segundo o Ministro Relator:

Em síntese, o dever-poder conferido ao magistrado para apreciar os fatos públicos e notórios, os indícios e presunções por ocasião do julgamento da causa não contraria as demais disposições constitucionais apontadas como violadas. A possibilidade de o juiz formular presunções mediante raciocínios indutivos feitos a partir da prova indiciária, de fatos publicamente conhecidos ou das regras da experiência não afronta o devido processo legal, porquanto as premissas da decisão devem vir estampadas no pronunciamento, o qual está sujeito aos recursos inerentes à legislação processual.

O problema ao qual os ministros não se atentaram é que a figura viciada da livre apreciação expressa no dispositivo é fundamento para a perpetuação da prática condenável de decidir com base em elementos não

${ }^{6}$ STF, ADI no 1.082/DF. Rel. Min. Marco Aurélio. Publicação DJE, em 30 de abr. de 2014. 
submetidos à apreciação das partes. Deve ser ressaltado que com relação à constatação ex officio de fato novo nada há de problemático, aliás, o Novo CPC admite essa possibilidade no art. 493, parágrafo único ${ }^{7}$, apenas reforçando a necessidade de se observar o contraditório e evitar surpreender as partes com decisões inesperadas, garantia omissa na redação do art. 23, da LC n⿳⺈ 64/90, e que resulta na violação do princípio da não surpresa e da necessidade de ampla fundamentação (STRECK, 2015).

Outro ponto elencado pelo Min. Marco Aurélio, e posteriormente destacado no voto do Min. Luiz Fux, para fundamentar a decisão é que a indisponibilidade dos direitos e interesses envolvidos no processo eleitoral permite ao juiz conhecê-los de ofício, sem ser provocado pelas partes.

Sobre esse ponto cabe a advertência que Theodoro Jr. (2011) fazia ainda sob a vigência do antigo código; segundo o doutrinador, mesmo que normas impositivas e indisponíveis sejam aplicadas de ofício pelo juiz, só o podem ser no limite necessário para solucionar o litígio descrito pelas partes. A interpretação a que se chega é que, uma vez que o processo se encontra devidamente instruído pelas provas trazidas e debatidas pelas partes, não deveria o magistrado, como terceiro elemento do processo, trazer, de ofício, material não apresentado pelos litigantes, pendendo o resultado da causa ao lado que ele, na avaliação moral de sua consciência, acredita ser a verdade real. Ao fazer assim, o julgador desestabiliza a paridade entre as partes e rompe com o contraditório substancial.

Em verdade, o Supremo Tribunal Federal deixou passar a oportunidade de extirpar do ordenamento jurídico norma maculada pela inconstitucionalidade por não garantir direitos processuais fundamentais. Mesmo que houvesse o receio de prolatar uma decisão tão impactante quanto uma declaração de inconstitucionalidade, o Tribunal poderia ter se valido do art. 28, parágrafo único, da Lei n⿳0 9.868/99, para dar interpretação conforme a Constituição ao dispositivo questionado. Dessa forma, estar-se-ia primando pelo atendimento ao princípio de presunção de constitucionalidade das leis, mas com o uso de uma técnica que serve para excluir interpretações inconstitucionais da norma, um método para colmatar lacunas, nas palavras de Meyer (2017). No entanto, não foi esse o caminho enveredado pelo STF, o qual preferiu manter a interpretação moralista da preservação do interesse público de lisura eleitoral.

${ }^{7}$ Se constatar de ofício fato novo, o juiz ouvirá as partes sobre ele antes de decidir. 
Essa expressão, “interesse público de lisura eleitoral”, é também deveras perigosa. Faria (2016) critica esse tipo de dispositivo, colocando que a legitimidade da Justiça Eleitoral não afasta a necessidade de que sejam observadas as garantias processuais de todos os litigantes.

Ferreira e Mezzaroba (apud TAVARES; AGRA, 2016) se somam aos que condenam a expressão, dizendo tratar-se de uma noção vaga e que se sobrepõe aos direitos fundamentais quando, na verdade, deveria ser lida com a mitigação do art. 489, \$1ํㅡㄹ do Novo CPC; deixam estampado, inclusive, a contradição existente entre a jurisprudência eleitoral com o compromisso do Estado Brasileiro em assegurar o desenvolvimento progressivo dos direitos políticos, como determinado na Convenção Americana sobre Direito Humanos. A decisão nos moldes do art. 23 da LC 64/90, em nome da lisura eleitoral, revela um retrocesso da garantia dos direitos fundamentais.

O que o artigo em debate revela é que, embora sejam responsáveis por garantir o respeito ao jogo democrático e ao resultado das urnas, os aplicadores do Direito Eleitoral atuam como tribunais morais e inquisitoriais, preocupados com o alcance de uma ideia transviada de moralidade coletiva que atropela as garantias individuais no processo.

Ao conteúdo muitas vezes restritivo e populista das leis eleitorais (elaboradas por parlamentares na busca de atender aos anseios da população) soma-se a postura controversa da jurisprudência especializada, que manifesta uma atuação bélica (PEREIRA, 2013) para restringir os exercícios políticos dos candidatos. Em analogia à corrente do Direito Penal Máximo, Pereira (2013) insinua que vivemos um período de Direito Eleitoral Máximo, no qual o candidato é o inimigo contra o qual é preciso armar barricadas e flexibilizar direitos.

Pela redação do art. 23, da Lei de Inelegibilidades, vê-se que é exatamente isso o que ocorre, já que meras presunções se sobrepõem ao exercício dos direitos políticos.

Há, como é de se esperar, aqueles que defendem a necessidade de um dispositivo com esse viés moralizador. É o caso de Gomes (2016) que, ao analisar o art. 23, defende que a natureza e as peculiaridades do processo eleitoral demandam que o juiz esteja sintonizado com o contexto político ao seu redor, sob pena de cometer injustiças. No mesmo sentido, Castro (2012, p. 443-4), promotor eleitoral, defende a lisura das eleições como bem jurídico maior a ser tutelado e protegido contra a influência do abuso 
de poder, mantendo o juiz "olhos e ouvidos abertos para perceber o abuso onde quer que ele se esconda”. Para o representante do Ministério Público, "o juiz deve estar no mundo das eleições, percebendo seus movimentos, não se admitindo que se acovarde no fundamento de que o que não está nos autos não está no mundo para o juiz".

Do outro lado, Costa (2016) acredita ser o art. 23 um "excesso do legislador", que outorgou ao juiz eleitoral poderes incompatíveis com o contraditório e com o Estado Democrático de Direito. Pondera que se às partes não for dado o conhecimento prévio dos fatos apurados para exercerem o direito de plena defesa, a decretação de inelegibilidade seria um absurdo a ferir a consciência jurídica. A ele se juntam os apelos de Salgado e outros (apud TAVARES; AGRA, 2016), quando dizem que o art. 23 elimina a previsibilidade, a segurança jurídica, a confiança legítima, o contraditório, a ampla defesa e o devido processo legal, cuidando a Justiça Eleitoral de ceifar a vontade dos eleitores quando, contraditoriamente, a preservação do interesse público exige justamente que a anulação de uma eleição esteja fundada em provas firmes.

\section{Aplicação Supletiva ou Subsidiária do Novo CPC ao Processo Eleitoral}

Defendendo ou condenando a carga moralizadora que permeia o Direito Eleitoral, não há como negar que a redação e a interpretação dada ao art. 23, da LC no 64/90, são incompatíveis com o regime do Novo CPC, em especial com os dispositivos dos art. 10, 371 e 489, aqui já trabalhados. Todavia, ainda há aqueles que resistem à aceitação da premente contradição, como é o caso de Esmeraldo (2016, p. 325) ao defender a compatibilidade dos institutos:

[...] entendo que o art. 23 da LC no 64/90 é constitucional e compatível com o diploma processual, dado que a norma que dela se extrai não autoriza o julgamento com base em fatos não alegados pelas partes ou não constantes nos autos, tampouco com base em indícios ou presunções. Como dito, admite-se apenas que esses elementos, contíguos às provas produzidas durante a instrução processual, participem da formação do convencimento do órgão julgador; entretanto, sua razão de decidir deverá sem embasada em provas contundentes 
constantes nos autos, sobre as quais as partes tenham tido a oportunidade de se manifestar, restando garantidos o contraditório, a ampla defesa e a fundamentação das decisões.

De fato, a leitura que a autora faz tem seus fundamentos, mas somente porque não considera a excepcional carga subjetiva dos juízes e tribunais eleitorais na livre apreciação dos fatos, sem a devida fundamentação e garantia do contraditório. Talvez as ideias da autora encontrassem maior respaldo caso o STF tivesse adotado a técnica de interpretação conforme a Constituição na análise de inconstitucionalidade do art. 23, como alhures debatido. Contudo, como não foi esse o resultado, a análise viciada do dispositivo continuou servindo de fundamento para que o magistrado eleitoral, na crítica de Salgado e outros (apud TAVARES; AGRA, 2016), assuma um dos lados na persecução eleitoral, e analise fatos não alegados ou tome conclusões lastreadas em presunções sem base legal.

Se para o STF o artigo debatido nada tem de problemático, como então compatibilizá-lo com o processo civil?

De início, Streck (2015) lembra que a Lei de Inelegibilidades veio pela previsão do art. 14, parágrafo 9º da Constituição, segundo o qual caberia à lei complementar estabelecer casos de inelegibilidade e os prazos de sua cessação. Vê-se que o dispositivo constitucional diz respeito tão somente à matéria de direito material de inelegibilidade, ou seja, o que não fosse direito material poderia ser objeto de atos normativos de natureza diversa, como lei ordinária.

É justamente aí que se enquadra o art. 23, da LC no 64/90, porquanto dispor sobre direito processual, matéria apreciável por lei ordinária. Pelo tanto, a parte processual da Lei de Inelegibilidades, em especial o art. 23, pode ser alterada por outra lei ordinária, tal qual o Código de Processo Civil, diante de incompatibilidade entre elas.

Soma-se a isso a leitura do art. 15 , do Novo $\mathrm{CPC}^{8}$, a partir do qual Theodoro Jr. (2015) explica que o Código não disciplina apenas a jurisdição civil, mas funciona como principal fonte do direito processual no ordenamento jurídico pátrio como um todo. Pela simples leitura do texto do artigo, bastaria demonstrar a inexistência de norma eleitoral específica

\footnotetext{
${ }^{8} \mathrm{Na}$ ausência de normas que regulem processos eleitorais, trabalhistas ou administrativos, as disposições deste Código lhes serão aplicadas supletiva e subsidiariamente.
} 
sobre a fundamentação das decisões no processo eleitoral para respaldar a aplicação do código processual.

No entanto, adverte Andrade Neto (apud TAVARES; AGRA, 2016), esse é um raciocínio circular insuficiente, tendo em vista que é o próprio código que diz que ele incide no processo eleitoral. A essa fundamentação devem se somar outras encampadas pela literatura jurídica, tendo Andrade Neto (apud TAVARES; AGRA, 2016) divido-as entre as razões de aplicação supletiva e as de aplicação subsidiária do Novo CPC.

A aplicação supletiva encontra campo no preenchimento de lacunas legais ${ }^{9}$. É a técnica que justifica a aplicação do Novo CPC caso se considere que a lei eleitoral não apreciou, em seus procedimentos, matéria sobre fundamentação e garantias processuais fundamentais. Essa interpretação faz uma leitura do art. 23, da LC nº 64/90, como instrumento omissivo e que, portanto, demandaria a suplementação de conteúdo por outra norma.

Para Andrade Neto (apud TAVARES; AGRA, 2016), a fundamentação para essa leitura poderia ser encontrada no art. $2^{\circ}, \$ 2^{\circ}$, da Lei de Introdução às Normas do Direito Brasileiro ${ }^{10}$. Segundo o autor, embora o Novo CPC, como norma geral, não revogue a legislação eleitoral extravagante, pois que especial, decorre do dispositivo da LINDB que as regras do Novo CPC incidem caso não haja normas processuais eleitorais.

Um pouco mais elaborada é a ideia de que a lei eleitoral não é omissa quanto às garantias processuais, mas que permite ao juiz atuar sem observá-las, podendo integrar um dos lados da persecução eleitoral, examinar fatos não alegados, e tirar conclusões baseadas em presunções sem base legal (STRECK, 2015).

Por essa ótica, ao invés do instrumento ser omissivo, teria um viés permissivo, mas com carga negativa e restritiva de direitos. Nesse caso, restaria patente uma situação de antinomia entre a LC nำ 64/90 e o Novo CPC e, para tanto, fala-se em aplicação subsidiária. O problema na aplicação subsidiária, acaso se entenda pela antinomia, é que aquela esbarra nas técnicas tradicionais de resolução de conflitos entre normas. Explica-se.

\footnotetext{
${ }^{9} \mathrm{Na}$ acepção de Bobbio (1999), lacuna é a falta de uma norma para regular o caso, gerando um problema de incompletude no ordenamento. Difere da antinomia, que ocorre quando no ordenamento há normas que são incompatíveis entre si (p. 81).

${ }^{10}$ A lei nova, que estabeleça disposições gerais ou especiais a par das já existentes, não revoga nem modifica a lei anterior.
} 
Do art. $2^{2}$, $\$ 1^{\varrho}$, da LINDB ${ }^{11}$ extrai-se a positivação da máxima lex posteriori derogat priori. Em um primeiro momento, o mero fato de o Novo CPC ser posterior à Lei das Inelegibilidades poderia ser suficiente para justificar a aplicação subsidiária, no entanto, a complexidade do caso reside em que a LC nº 64/90 é especial em relação ao código processual, atraindo o critério da especialidade (lex specialis derogat generali). Tem-se formada uma incompatibilidade de segundo grau (BOBBIO, 1999), ou seja, que não se dá entre normas, mas entre os critérios válidos para a solução da incompatibilidade entre as normas. Para essa situação Bobbio (1999, p. 108) apresenta a solução pela regra lex posterior generalis non derogat priori speciali:

Com base nessa regra, o conflito entre critério de especialidade e critério cronológico deve ser resolvido em favor do primeiro: a lei geral sucessiva não tira do caminho lei especial precedente. O que leva a uma posterior exceção ao princípio lex posteriori derogat priori: esse princípio falha, não só quando a princípio lex posteriori é inferior, mas também quando é generalis (e a lex prior é specialis).

Pelas lições do mestre italiano (BOBBIO, 1999), contudo, a possibilidade de aplicação subsidiária do Novo CPC já estaria afastada. Para solucionar o impasse, os métodos tradicionais de interpretação e resolução de conflitos normativos devem ser lidos com adequação à vertente constitucional da hermenêutica, pautada pela primazia dos princípios constitucionais e direitos fundamentais.

Por esse caminho, Andrade Neto (apud TAVARES; AGRA, 2016) apresenta como justificativa da aplicação subsidiária do Novo CPC o caráter principiológico do Novo Código de Processo Civil, o qual foi elaborado primando pelas garantias processuais fundamentais a serem aplicadas no ordenamento como um todo (art. 15) e, principalmente, pelos princípios insculpidos na Constituição da República, nominado de "argumento dos sistemas de regras legais e princípios constitucionais” (ANDRADE NETO, 2016 apud TAVARES; AGRA, 2016, p. 373-4). Para além dos critérios tradicionais de resolução de antinomias prevaleceria o caráter axiológico do Novo CPC, ao garantir direitos processuais fundamentais, o que faz sentido se for considerada a ênfase que o movimento neoconstitucionalista confere aos princípios e à interpretação que se faz sobre eles.

\footnotetext{
${ }^{11}$ A lei posterior revoga a anterior quando expressamente o declare, quando seja com ela incompatível ou quando regule inteiramente a matéria de que tratava a lei anterior.
} 
A aplicação dos dispositivos do Novo CPC encontra, portanto, respaldo em diferentes frentes. A iniciar pela própria redação do art. 15, do codex, que, somado ao fato de o art. 23, da LC n⿳ 64/90, trazer conteúdo de lei ordinária - de mesma natureza que o Novo CPC -, permite que o código seja aplicável supletiva ou subsidiariamente ao processo eleitoral da Lei das Inelegibilidades, a depender da leitura que se faz de como a lei aborda as garantias processuais.

\section{Considerações Finais}

A partir do que foi brevemente exposto neste trabalho, vê-se que são duas as situações que se enfrentam: de um lado, encontra-se a lei de 1990, que trata de causas de inelegibilidade e o procedimento de sua investigação sem, contudo, apreciar os direitos e garantias prementes em um processo; de outro, há o Novo Código de Processo Civil, elencando os princípios norteadores do processo, de observação obrigatória pelas partes e pelo julgador na construção do contraditório substancial, além de expressamente ser aplicado supletiva e subsidiariamente aos processos eleitorais.

Qualquer interpretação em boa-fé do art. 23, da Lei das Inelegibilidades, partindo da teoria do processo, garantiria a observação dos princípios e das garantias gerais do processo na aplicação à seara eleitoral. Contudo, em razão da elevada carga moralizadora em torno do Direito Eleitoral, o que se vê é que não apenas a legislação, mas também a construção jurisprudencial na área faz uso do silêncio normativo para mitigar as garantias processuais fundamentais em prol da proteção de um bem jurídico notadamente vago, mas supostamente mais relevante, que é a lisura do pleito.

Se a aplicação do art. 23, da LC no 64/90, realmente atendesse aos princípios processuais, não haveria problemas em torno dele, e a decisão do Supremo Tribunal Federal na ADI no 1.082/DF faria sentido. Todavia, a realidade prática mostrou que o dispositivo não recebia a interpretação adequada, de forma que a melhor solução seria, como defendido, conferir interpretação conforme a Constituição ao artigo, medida que seria menos invasiva ao ordenamento, mas que garantiria a leitura da norma de forma mais condizente com a Constituição e com as garantias processuais.

Como a via do controle concentrado não resolveu o problema, a resolução do conflito gerado pelo choque entre os dois instrumentos legais resta nas técnicas de resolução. Conforme apontado, a natureza processual 
do art. 23, da LC n⿳ำ 64/90, possibilita seja ele alterado por lei ordinária, tal qual o Novo CPC. Daí cabíveis duas possibilidades ao aplicador da lei: se entender haver uma antinomia entre os dois instrumentos legais, com a lei eleitoral, permitindo a decisão sem as garantias fundamentais, encontra-se respaldo à aplicação subsidiária do Novo CPC e dos princípios da Constituição, com base em seu viés axiológico; se entender ser o caso de lacuna legal, pelo fato de a Lei das Inelegibilidades não se manifestar sobre o dever de fundamentação e respeito ao contraditório, há base para a aplicação supletiva do código processual, resolvendo o problema de incompletude do ordenamento.

Seja pela aplicação supletiva ou pela subsidiária, fato é que o art. 23 da LC 64/90, por se tratar de matéria processual, deve ser interpretado consoante a leitura do Novo CPC, vez que a lei eleitoral não tratou de garantir o respeito ao contraditório e ao dever de fundamentação, e o STF não se desincumbiu da tarefa de resolver a questão quando provocando para tanto.

\section{Referências}

ANDRADE NETO, João. Ponderação e dever geral de fundamentação no Direito Eleitoral. In: TAVARES, André Ramos; AGRA, Walber de Moura; PEREIRA, Luiz Fernando (Coord.). O direito eleitoral e o novo Código de Processo Civil. Belo Horizonte: Fórum, 2016. p. 359-379.

BOBBIO, Norberto. Teoria do Ordenamento Jurídico. 10. ed. Brasília: UnB, 1999.

BRASIL. Superior Tribunal de Justiça. AgRg em EREsp nº 319.997. Relator Min. Francisco Peçanha Martins. Brasília, publ. 07 de abril de 2003.

CASTRO, Edson de Resende. Curso de Direito Eleitoral. 6. ed. Belo Horizonte: Del Rey, 2012.

CINTRA, Antônio Carlos de Araújo; GRINOVER, Ada Pellegrini; DINAMARCO, Cândido Rangel. Teoria Geral do Processo. 30. ed. São Paulo: Malheiros, 2014.

COSTA, Adriano Soares da. Instituições de Direito Eleitoral. 10. ed. Belo Horizonte: Fórum, 2016. 
CUNHA, Leonardo Carneiro da. O princípio contraditório e a cooperação no processo. Disponível em: <http://www.leonardocarneirodacunha. com.br/artigos/o-principio-contraditorio-e-a-cooperacao-no-processo/>. Publ jun. 2013. Acesso em: 26 jun. 2017.

DIDIER JR., Fredie. Curso de Direito Processual Civil. Vol. 1. 13. ed. Salvador: Juspodivm, 2011.

. BRAGA, Paulo Sarno; OLIVEIRA, Rafael Alexandria de. Curso de Direito Processual Civil. Vol. 2. 10. ed. Salvador: JusPodivm, 2015.

ESMERALDO, Elmana Viana Lucena. Processo Eleitoral. 3. ed. Leme: JH Mizuno, 2016.

FARIA, Fernando de Castro. Uma releitura do artigo 23 da Lei Complementar 64/90 sob a mirada do novo Código de Processo Civil. Empório do Direito. Disponível em: <http://emporiododireito.com.br/uma-releitura-do-artigo-23-dar-6490-sob-a-mirada-do-no-lei-complementavo/>. Publ ago. 2016. Acesso em: 26 jun. 2017.

FERREIRA, Marcelo Ramos Peregrino; MEZZAROBA, Orides. Conceitos jurídicos indeterminados no Direito Eleitoral: um olhar a partir da necessidade de fundamentação nas decisões judiciais prevista no Novo Código de Processo Civil. In: TAVARES, André Ramos; AGRA, Walber de Moura; PEREIRA, Luiz Fernando (Coord.). O direito eleitoral e o novo Código de Processo Civil. Belo Horizonte: Fórum, 2016, p. 381-398.

GOMES, José Jairo. Direito Eleitoral. 12. ed. São Paulo: Atlas, 2016.

GONÇALVES, Aroldo Plínio. Nulidades no Processo. 2. ed. Belo Horizonte: Del Rey, 2014.

MARINONI, Luiz Guilherme; ARENHART, Sérgio Cruz; MITIDIERO, Daniel. Novo curso de Processo Civil. Vol. II. São Paulo: Revista dos Tribunais, 2015.

MEYER, Emilio Peluso Neder. Decisão e Jurisdição Constitucional. Rio de Janeiro: Lumen Juris, 2017.

MOREIRA, José Carlos Barbosa. A motivação das decisões judiciais como garantia inerente ao Estado de Direito. Revista Brasileira de Direito Processual. V. 16. Rio de Janeiro: Forense, 1978.

PEREIRA, Rodolfo Viana. Direito eleitoral contra o inimigo. In: Em Debate. Belo Horizonte, Vol. 5, n. 4, p. 26-30, out. 2013. 
RAMINA DE LUCCA, Rodrigo. O dever de motivação das decisões judiciais. Salvador: JusPodivm, 2015.

SALGADO, Eneida Desiree; VALIATI, Thiago Priess; BERNARDELLI, Paula. O livre convencimento do juiz eleitoral versus a fundamentação analítica exigida pelo novo Código de Processo Civil. In: TAVARES, André Ramos; AGRA, Walber de Moura; PEREIRA, Luiz Fernando (Coord.). O direito eleitoral e o novo Código de Processo Civil. Belo Horizonte: Fórum, 2016, p. 335-358.

SILVA, Blecaute Oliveira; ROBERTO, Welton. O contraditório substancial no projeto do Novo CPC. In: FREIRE, Alexandre; DANTAS, Bruno; NUNES, Dierle; DIDIER JR., Fredie; MEDINA, José Miguel Garcia; FUX, Luiz; CAMARGO, Luiz Henrique Volpe; OLIVEIRA, Pedro Miranda de. (Org.) Novas tendências do Processo Civil. Vol. II. Salvador: JusPodivm, 2014.

STRECK, Lenio Luiz. O que é isso: "decidir conforme a consciência”?: protogênese do protagonismo judicial. In: MACHADO, Felipe; CATTONI, Marcelo (Coord.). Constituição e processo: entre o direito e a política. Belo Horizonte: Fórum, 2011, p. 215-250.

. O que é a livre convicção dos indícios e presunções? Consultor Jurídico. Disponível em: <http://www.conjur.com.br/2014-fev-13/senso-incomum-livre-conviccao-indicios-presuncoes?>. Publ fev. 2014. Acesso em: 26 jul. 2017.

. Julgar por presunção no direito eleitoral é compatível com novo CPC? Consultor Jurídico. Disponível em: <http://www.conjur.com. br/2015-nov-05/senso-incomum-julgar-presuncao-direito-eleitoral-compativel-cpc?>. Publ nov. 2015. Acesso em: 26 jul. 2017.

TARUFFO, Michele. Apuntes sobre las funciones de la motivación. Revista Iberoamericana de Derecho Processual. Vol. 4/2016. São Paulo: Revista dos Tribunais, jul-dez 2016, p. 237-249.

THEODORO JÚNIOR, Humberto. Curso de Direito Processual Civil. Vol. I. 52. ed. Rio de Janeiro: Forense, 2011.

. Curso de Direito Processual Civil. Vol. I. 56. ed. Rio de Janeiro: Forense, 2015. 
WAMBIER, Teresa Arruda Alvim; DIDIER JR., Fredie; TALAMINI, Eduardo; DANTAS, Bruno. Breves comentários ao Novo Código de Processo Civil. São Paulo: Revista dos Tribunais, 2015.

Rodolfo Viana Pereira - Doutor em Ciências Jurídico-Políticas pela Universidade de Coimbra. Mestre em Direito Constitucional pela UFMG. Pós-Graduado em Direito Eleitoral e Administração de Eleições pela Universidade de Paris II. Pós-Graduado em Educação a Distância pela Universidade da Califórnia, Irvine. Professor da Faculdade de Direito da UFMG. Fundador e Coordenador Acadêmico do IDDE - Instituto para o Desenvolvimento Democrático. Fundador e primeiro Coordenador Geral da ABRADEP - Academia Brasileira de Direito Eleitoral e Político. Advogado sócio da MADGAV Advogados.

Lucas Tavares Mourão - Mestrando em Direito pela Universidade Federal de Minas Gerais. Especialista em Direito Constitucional pelo Instituto para o Desenvolvimento Democrático, em parceria com o Centro de Direitos Humanos da Universidade de Coimbra (Portugal). Bacharel em Direito pela Universidade Federal de Minas Gerais. Monitor do Grupo de Estudos em Constituição e Política. Advogado. E-mail: lucastmourao@gmail.com. 
